\title{
腕神経叢神経鞘腫の二症例
}

\author{
飯塚 桂司・戸川清・今野 昭義 \\ 東 紘一郎・藤原 隆行・井上 周一
}

\section{Two Cases of Neurilemmoma of the Brachial Plexus}

\author{
Keiji Iizuka, Kiyoshi Togawa, Akiyoshi Konno, Koichiro Higashi, \\ Takayuki Fujiwara, Shuichi Inoue
}

(Akita Univ.)

A 47-year-old woman complained of a painless swelling on the right lateral neck, which grew slowly for 5 months after discovery. Weak pain radiating out the arm and the hand was experienced by palpation.

Examination revealed an about $5 \times 7 \mathrm{~cm}$, firm, fixed mass with tumor vessels in the right supraclavicular region. There was also a palpable nodular lesion in the right lobe of the thyroid. Calcification on a plain film and a cold nodule in thyroid scintigram were evident.

A right hemithyroidectomy with radical neck dissection was performed for malignant struma and cervical metastasis. The nodular lesion in the thyroid proved to be a follicular adenoma, and the lateral neck tumor was a neurilemmoma of Antoni-A type, arising in the brachial plexus.

A 67-year-old man underwent incomplete resection of the right infraauricular tumor in a certain hospital, and ulcerative change and sialorrhea then appeared.

After twice sessions of cryosurgery, the tumor became a painful mass and he was introduced to our clinic.

A fixed mass of about $5 \times 7 \mathrm{~cm}$ was noted in the right infraauricular and submandibular region and there was an ulcerative lesion of about $3 \mathrm{~cm}$ in diameter, bulging into the lumen of the pharynx. Examination revealed calcification on a plain film and abnormal accumulation of ${ }^{67} \mathrm{Ga}$ citrate in scintigram.

Suspected of being a malignant tumor of the parotid gland, the patient underwent a total parotidectomy with facial nerve preservation, radical neck dissection and partial pharyngectomy. The pathology revealed a ganglioneuroma.

After 2 months, a firm, fixed, slightly tender tumor, about the size of the tip of the thumb could be palpated in the left supraclavicular region. Surgery revealed a neurilemmoma of Antoni-A type beneath the anterior scalenus muscle.

$$
\text { I はじめ に }
$$

神経鞘腫は，神経鞘より発生する腫瘍であり， Schwann 氏鞘を有する脳脊髄神経本幹より末梢 
に至るまで, 全身至る所広範囲に発生する。頭頸部領域に発生する神経鞘腫の頻度は全体の約 25〜 $35 \% \%^{12)}$ 之言われ, 聴神経腫瘍が圧倒的に多いが, 舌, 咽頭, 鼻腔, 頸部, 顔面にも発生する ${ }^{3}$.

文献的な年令分布では，特にピークはないが，30４0歳台に多く，発生頻度に著しい性差はない と言われる4!

今回，われわれの経験した二例の腕神経叢に発生した神経鞘腫を報告するととむに，頸部神経鞘 腫について考察を加えた。

\section{II 症}

\author{
症 例 1 ：47歳, 女性. \\ 初部：昭和52年11月 10 日. \\ 主 訴: 右頸部腫瘤.
}

家族歴：特記すべきことなし。

既往歴：28歳, 虫垂炎手術及び再手術.

42歳, 高血圧.

現病歴：昭和 52 年 6 月頃，右側頸部の腫脹に 気付くが放置. 増大傾向があり同年11月近医を 受診したととろ，当科へ紹介となる，疼痛，局 所熱感はないが，腫瘤を圧迫すると右上腕から 手指にかけて柽い疼痛を感じたととがあったと 言う。嗄声や曼下困難はない.

現症：甲状腺右葉下部に弾性硬の小腫瘤と右 側頸部に約 $5 \times 7 \mathrm{~cm}$ の卵形で深部之癒着のある 硬い表面平滑な腫瘤を触知. 圧痛はなく初晾時 圧迫によって右上肢への疼痛はなかった。反回 神経麻瘏は認められず, その他身体的理学的所 見はない。

臨床検查所見では, 尿, 末梢血, 肝機能, 血 清蛋白分画, 電解質は正常. 甲状腺機能は euthyroidism であるが, 喉頭X線にて気管圧排 像及び石灰化沈着を示し，甲状腺シンチグラム にて, cold tumor nodule を認める. 胸部X線 では軽度心肥大を示す他所見なく, ${ }^{67} \mathrm{Ga}$ tumor scan 及び ${ }^{99 \mathrm{~m}} \mathrm{Tc}$ bone scan にも異常集積は なかった。

ACTA scan : 右側頸部に, 辺縁平滑, 境界 明暸な mass があり, 右総頸動脈, 内頸静脈 を前方八圧排しているが, 甲状腺との連続性は 認められない.

血管造影 : 右総頸動脈は前方, やや内側へ圧 排され，上行頸動脈は軽度伸展，その分枝より
例

腫瘍血管を認める，従って甲状腺の後外側に存 在する悪性腫瘍が考えられる (第 1 図).

経過：悪性甲状腺腫及び頸部リンパ節転移を 考えて甲状腺右葉切除術, 右頸部郭清術を施 行. 甲状腺腫は沪胞性腺腫（第 2 図）であり， 頸部腫瘤は前斜角筋の奥に位置し腕神経叢より 発生した神経鞘腫（Antoni A型）であった ( 3 第, 4 図).

\section{症例 2 : 67歳, 男性.}

初彰：昭和52年 10 月 26 日.

主訴 : 右耳下部・顎下部の潰晹性腫熘.

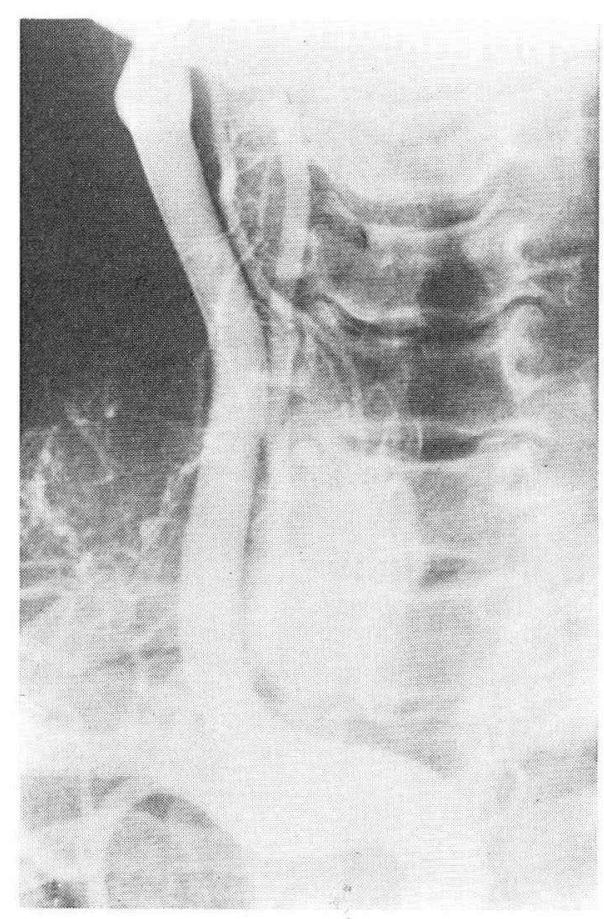

第 I 図 血管造影

上行頸動眽の軽度伸展と腫瘍血管がみられる。 


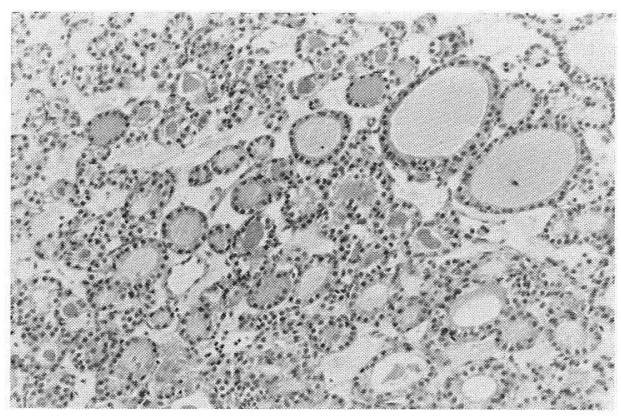

第 2 図 組織像 (H.E. $\times 100)$

主に小型の濾胞から成り，コロイドが允満している.

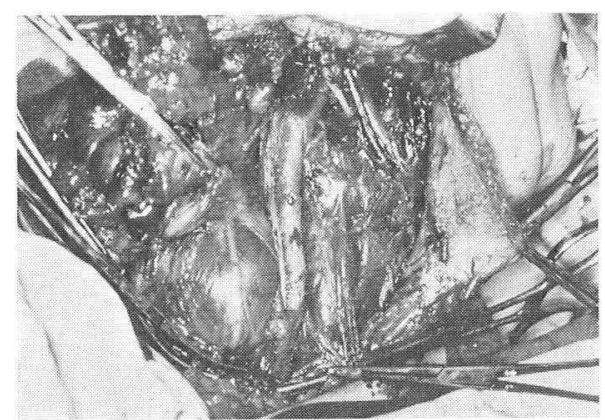

第 3 図 前斜角筋の奥に位置する平滑な巨大腫場がみ られる。

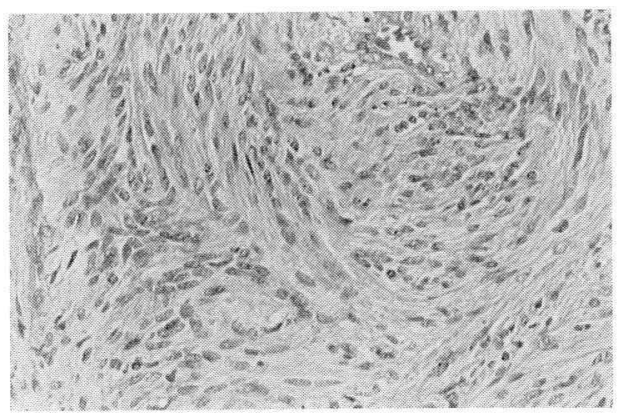

第 4 図 組織像（H.E. $\times 200 ）$

紡釷形細胞が密在性に增殖し，䒽状配列を示す．

家族歴：特記すべきととなし。

既往歴：17歳，結核性胸膜炎.

現症：昭和 12 年頃, 右耳下部に示指頭大の腫 瘤に気付き, 某病院外科にて摘出術を受けた が, 出血が多く中止. 以後, 右上肢の柽度運勤 障害を残す。昭和 42 年與下障害が出現し, 次第
に摄食時むせるようになり喀痰增加，又，嗄声 が強くなり某病院にて胸膜炎, 気管支炎の治療 を受ける。同病院にて耳下部腫瘤の生検を受 け，“良性、と言われたが，後に唾液瘻が現わ れ潰瑒性病変となる。昭和 52 年， 2 回の冷凍手 術を受けたが軽快せず疼痛む加わり当科紹介と なる。

経過：耳下部・顎下部に約 $5 \times 7 \mathrm{~cm}$ の腫瘤が あり中央に約径 $3 \mathrm{~cm}$ 潰瘍形成があって周用之 瘉着している(第 5 図)，咽頭右側は球状に街隆 し，腫賌は内頸動脈の直後にまで及んでいる. 顔面神経麻瘦はない。

臨床検查所見にて，末梢血に軽度貧血を認め る他異常なく, 尿, 朋機能, 電解質は正常. W a-R (+), TPHA 640倍. 耳下腺部X線にて 咽頭右側壁の膨隆を示し腫瘍内石灰化を認める が，唾影像では，上方への圧排のみでほぼ正常 である，胸部X線にて著明な気管偏位と左肺野 の強い陰影, 高度の胸膜癒着を示し，呼吸機能 あ低下している.

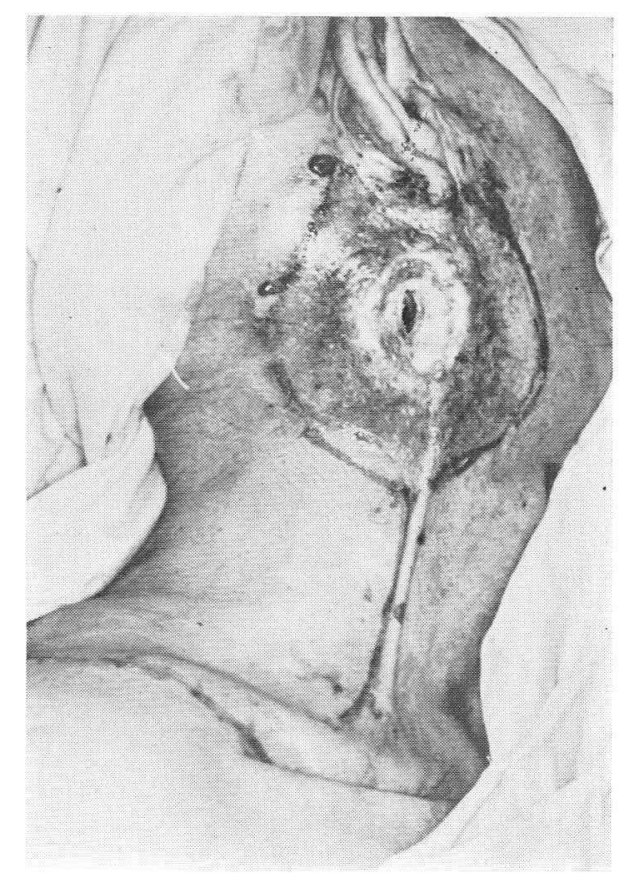

第 $\mathbf{5}$ 図 右耳下部・擷下部に漬婸を形成した腫瘤がみ られる。 
術前に試験切除を行ったが, 変性・壊死組織 のみであった。

ACTA scan : 右耳下腺領域に大きな腫痬を 認め内側へ広範围に浸潤。中咽頭へ突出像を認 めるが骨破壊は明らかでない。

${ }^{67} \mathrm{Ga}$ scan：右耳下部・顎下部にかけて異常 集積を認めるが，右側面にて中心部の activity が少ない(第 6 図).

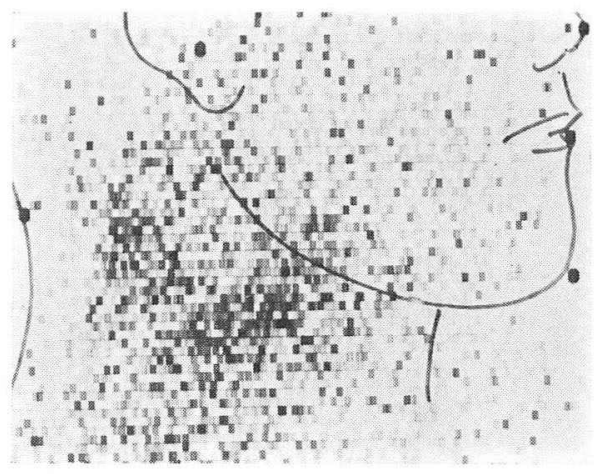

第 6 図 ${ }^{67} \mathrm{Ga}$ citrate シンチグラム.

腫場への異常集積を示すが，中心部の activity は， 少ない。

${ }^{99 \mathrm{~m}} \mathrm{Tc}$ scan : 左右耳下腺はよく描出されてい るが, 右側は耳下腺が上方へ押し上げられてお り，その後下方に activity の少ない所がある.

耳下腺腫瘍の悪性化を疑って顔面神経を剝離 保存し，潰瘍部皮膚を含めて耳下腺全摘，頸部 郭清術, 中咽頭側壁部分切除術を行ない両側 D-P 皮弁にて火損部を修復した。病理組織は, ganglioneuroma が疑われる (第 7 図).

術後, Horner 徵候, 舌下神経麻瘏, 咽喉頭

\section{III 考}

神経鞘腫は, 神経系腫煌でありながら原組織 の神経症状を呈することは殆んどないと言われ る. それは発生母地となる神経に知覚の要素に 乏しく, 更に神経束の外縁で腫瘍が発生し, 神 経束を側方へ圧排しつつ外方へ膨脹性に発育 し，神経が腫瘍の中にまきとまれることがない ためと思われる゙) 5).

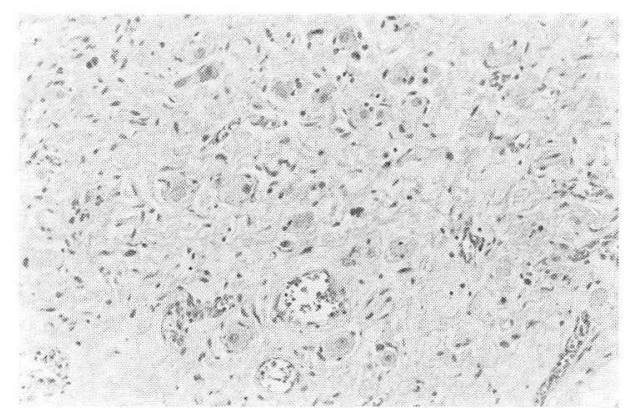

第 7 図 組織像 (H.E. $\times 100)$

神経節細胞と，不規則に交錯している神経線維束がみ られる。

㾁痺が現われ㫶下性肺炎のため気管切開を行な う. 約 2 力月後, 左側頸部に拇指頭大の腫瘤を 触知. 弾性硬, 底部に癒着し圧痛があり, リン パ節転移を疑って診断的摘出を行なったとて ろ，前斜角筋の奥にあり腕神経叢より発生した 神経鞘腫 (Antoni A型) であった (第 8 図).

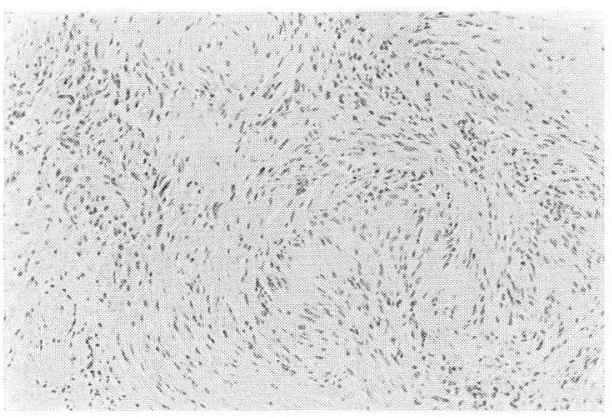

第 8 図 組織像 $($ H.E. $\times 100)$

紡鍾形の腫瘍細胞が柵状配列を示している.

按

頭頸部領域に発生した場合，臨床的に問題と なる症状は，腫瘍塊の存在による二次的なもの (massive effect) であり, 発生部位により多 彩な症状が出現する.

頸部神経鞘腫は, その発生部位から内側型之 外側型に大別される.内側型は, 舌咽, 迷走, 副, 及び舌下神経の 4 脳神経と頸部交感神経に 
由来するものであり, 解剖学的関係から咽頭や 喉頭など内腔への膨隆を来たし，気道狭窄や食 物の通過障害などの症状をひき起とす，外側型 は, 頸神経丵及び腕神経叢より発生し周团組織 への圧迫症状や外頸部への膨隆が主徵となって くる ${ }^{6)}$.

本症例では，前斜角筋の奥に位置し腕神経叢 より発生した神経鞘腫であり外側型に分類され る。症例 1 では，側頸部の腫脹が主訴となって おり，経過中に圧迫時上腕から手指にかけて疼 痛の既往があるが，腫瘤塊による圧痛であって 腫瘍による神経障害は生じていない。症例 2 で は，術後の経過中に触知され軽度の圧痛はある が，何ら神経徵候は示さなかった。

病理組織学的には, Antoni A型 (束状型) とAntoni B型（網状型）に基本的には大別さ れるが混合型む可成り多い78).

Antoni A 型は, 線維性腫崵組織であり, 双 極紡鍾型腫瘍細胞が束状となり，種々の方向に 錯走しながら密に増殖 (herring bone pattern)し，特徵的な柵状又は観兵式配列 (palisade, or parade arrangement) を呈する. 更 に細胞質塊により柵状構造をとる verocay body が見られる. Antoni B 型は，腫瘍の変性 過程とも見られ，粘液腫状であり，腫瘍細胞が 網状配列をとり小囊胞腔を取り囲んで粗な細網 線維網を形成している.

肉眼的には，良く被包化された実質性腫瘍で あり, 二次変性の結果, 囊胞形成や脂肪沈着を 示すことあある.

本症例は，いずれすよく被膜化された Antoni A 型を示す神経鞘腫であり, 症例 1 では巨 大腫瘤で栄養血管が認められた。

\section{IV 結}

頸部腫瘤の臨床では，鑑別診断が疾患への予 後を左右する上で重要である ${ }^{910) 111}$ 。 その理由 は，統計的発生頻度に执いて悪性腫瘍の占める

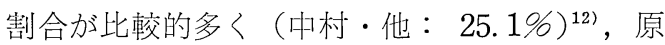
発性腫瘍に比べ転移性悪性腫瘍（中村・他：81. $9 \%)^{12)}$ が圧倒的に多いからである年(14). 従って 頸部腫瘤を主訴とした場合, 絶えず悪性疾患で ある可能性を考えて治療計画を立てなければな らない。

症例 1 では，主訴とする側頸部腫瘤が増大傾 向を有する固着した巨大腫瘍であり，血管造影 にて腫揚血管が認められたとと, 更に cold nodule を示す甲状腺腫を同時に認め，甲状腺 腫演の特殊な転移様式も考慮して悪性甲状腺腫 とその転移巣であることを第一に考えた。

症例 2 では臨床検査では悪性腫汮を疑わせな がら不適切な治療により耳下腺部腫瘍の組織の 確定診断が困難であったとと，及び術後に腫瘤 を触知したととなどより転移巣の可能性も考慮 した手術を施行した。

神経鞘腫は，良性腫瘍であって発育屯緩慢で あるが，頭頸部領域ではその発育に伴って sodesignated position malignancy ${ }^{15)}$ となるこ とが多い. 又, 放射線感受性に著しく乏しく, 外科的摘出が唯一の方法である。 が，悪性化が 極めて稀であり，被膜を残しても再発の可能性 は低いと言われているので，外方へ膨脹性に発 育することも考えて，特に重要な機能をあつ神 経に対しては，可及的剝離し神経線維を保存す るいわゆる intracapsular shelling out ${ }^{16)}\left(\right.$ 被 $^{2}$ 膜下全剔) ${ }^{17) 18)}$ をするととが望しい.

本症例では，いずれも被膜下全剔し著明な術 後の機能障害は来たさなかった.

\section{語}

腕神経叢より発生した神経鞘腫の二症例を報告した。いずれも頸部腫瘤が複数存在するため術前 診断は困難で, 主病巣一転移巣の関係で悪性腫瘍に対処できる状態で外科的摘出を行なった.

二症例とむよく被膜化された Antoni A型を示す神経鞘腫であり，被膜下全剔を施行し術後の神 経障害は認められなかった。 
1) Putney, F. J., et. al. : Neurogenic tumors of the head and neck. Laryngoscope $74: 1037 \sim$ 1058, 1964.

2 ) Conley, J. J. : Neurogenous tumors in neck.. Arch. Otolaryng. 6I : 167 180, 1966.

3) 日野原正, 他：耳鼻咽喉科領域の神経鞘腫につい て. 耳展 13:11 17, 1970 .

4) 野村恭也, 他：咽頭ノイリノーム—文献的考察 ならびに二症例報告—. 耳喉 $43: 371 〜 378$, 1971.

5 ) 武川昭男：神経線維腫・神経鞘腫. 耳喉 $49: 777$ 〜86, 1977.

6) Daly, J. F., et. al. : Neurilemmoma of the cervical sympathetic chain. Arch. Otolaryng. $77: 262 \sim 267,1963$.

7 ) 小泉智, 他: 舌根部 Neurinoma の 1 症例. 耳 喉 $49: 587 \sim 590,1977$.

8 ) Masson, P. : Experimental and spontaneous Schwannomas II (peripheral gliomas). Amer. J. Path. $8389 \sim 415$, 1932.

9 ）植草実, 他 : 頸部腫瘤の臨床診断. 外科診療 13 : 1123 1129, 1971.

10) Cady, B. : Evaluation of neck masses. Surg.
Clin. of North Am. $50: 559 \sim 566,1970$.

11）佐藤文彦, 他：頸部腫瘤の臨床的観察——転移性 頸部腫瘤—. 癌の臨床 $18: 197 \sim 202,1972$.

12）中村昭郎，他：頸部腫瘤-一過去五年間の統計的 観察—. 耳鼻臨床６5：1261～1268， 1972.

13) Skandalakis, J. E. : Tumors of the neck. Surg. $48: 375 \sim 384,1960$.

14) Skolnik,E. M. : Swellings of the neck. Arch. Otolaryng. 81:150 152, 1965.

15) Motley, F. E. : Position malignancy. Arch. Otolaryng. $34: 771 \sim 786,1941$.

16) Altany, F. F., et. al. : Neurilemmomas of the vagus nerve in the neck. Arch. Surg. $73: 793 \sim 800,1956$.

17）広瀬肇，他：頸部交感神経原性と思われた neurinoma の1例. 日耳鼻 $68: 1241 \sim 1247,1965$.

18) Godwim, J. T. : Encapsulated neurilemmoma (Schwannoma) of the brachial plexus. Cancer $5: 708 \sim 720,1952$.

原稿到着：昭和54年 1 月25日 別刷請求先：飯塚桂司 于010 秋田市本通 1 丁目 1 番 1 号 秋田大学医学部耳鼻咽喉科学教室 